\title{
„Pessi týpíska óörugga stelpa“: Greining á sögum ungra kvenna um holdafar og stefnumót
}

\author{
Sólveig Sigurðardóttir og Annadís G. Rúdólfsdóttir \\ Abstract \\ - Um höfundana \\ About the authors \\ Heimildir
}

Markmið pessarar rannsóknar var að greina hugmyndir ungra kvenna (18-24 ára) um vægi holdafars í tengslum við stefnumót. Fræðilega sjónarhornið er femíniskur póststrúktúralismi en gagna var aflað með sögulokaaðferð par sem pátttakendur fengu upphaf að sögu sem peir voru beðnir um að ljúka. Dátttakendur fengu ýmist söguupphaf par sem söguhetja, sem var að fara á stefnumót, hafði grennst eða fitnað. Alls voru 72 sögur pemagreindar. Í sögum pátttakenda voru póstfemíniskar hugmyndir áberandi en fjögur pemu voru greind: (1) Líkaminn má ekki valda (honum) vonbrigðum. Dar kom fram að grannir líkamar hafa meira virði en feitir á vettvangi stefnumótamenningar og að pað sé á ábyrgð sögupersónunnar að tryggja að virði hans sé sem mest. (2) Sjálfstraust og líðan tengist ánægju sögupersónu með útlit sitt. Í pví pema kom fram að tilhugsunin um að fitna eða vera feit fyllti sögupersónuna kvíða og óöryggi. Degar hún grenntist einkenndust sögurnar aftur á móti af gleði og aukinni eftirvæntingu fyrir stefnumótinu. Nokkrar sögur greindu einnig frá vonleysi sögupersónunnar pegar hún áttaði sig á pví að sama hversu mikið hún grenntist pá var pað aldrei nóg. (3) Líkaminn og sjálfið sem verkefni. Í pví pema kom fram að vinnan og eftirlitið með líkamanum er stöðugt ferli og ekki hægt að slá slöku við. (4) Andóf gegn útlitskröfum felst í að taka líkamann í sátt. Í pví pema mátti greina andóf gagnvart ríkjandi útlitskröfum, sérstaklega í sögum par sem sögupersónan hafði fitnað. Áhersla var lögð á að gefa ríkjandi hugmyndum langt nef og taka líkama sinn í sátt. Rannsóknin gefur innsýn í flókin tengsl ungra kvenna við menningarbundnar hugmyndir um líkamann og hversu mikillar vinnu við líkamann kvenleikinn krefst af peim. Hún sýnir einnig hversu gagnleg sögulokaaðferðin er til að fá innsýn í kynjaðar menningarbundnar hugmyndir og pau tök sem pær hafa á ungum konum.

Efnisorð: Kyngervi, holdafar, kvenleiki, póstfemínismi, sögulokaaðferð

\section{Inngangur}

Reglulega birtast fréttir í fjölmiðlum af lágu sjálfsmati og miklum kvíða ungra kvenna sem oft er sett í samhengi við útlitsdýrkun samfélagsins og óraunhæfar líkamsmyndir (til dæmis Aníta Estíva Harðardóttir, 2018). Rannsóknir sem mæla áhrif slæmra líkamsmynda á líðan og sjálfstraust ungs fólks á Íslandi ítreka pessi tengsl (Sigríður T. Eiðsdóttir, Álfgeir L. Kristjánsson, Inga Dóra Sigfúsdóttir, Garber og Allegrante, 2013). Raunar virðist sem svo að óánægja með líkamspyngd sé almenn á meðal kvenna á Íslandi og að hún vari nánast í gegnum allt lífshlaupið (Erna Matthíasdóttir, Stefán Hrafn Jónsson og Álfgeir Logi Kristjánsson, 2010). Fáar rannsóknir liggja pó fyrir sem kryfja pá menningarlegu og félagslegu pekkingu sem liggur að baki hugmyndum ungra kvenna um útlit og holdafar (sjá pó Ásta Jóhannsdóttir, 2018).

Í pessari rannsókn söfnuðum við sögum frá ungum konum til að fá innsýn í pað hvað ungar konur sjá fyrir sér að gerist í lífi kvenna sem hafa fitnað eða grennst og pá sérstaklega í samhengi við pað að vera að fara á stefnumót. Við nálgumst viðfangsefnið frá sjónarhorni femínisks póststrúktúralisma 
(Annadís Greta Rúdólfsdóttir, 1997; Bordo, 1993; Gavey, 1989;; Weedon, 1987). Í anda Foucault (1981) skoðum við hvernig hugmyndir um kyngervi og holdafar eru hluti af orðræðum sem móta reynslu karla og kvenna og viðhorf til líkamans. Við greinum pær hugmyndir sem sögurnar byggja á og hvernig pær staðsetja ungar konur í orðræðum samfélagsins. Áður en rannsókninni sjálfri eru gerð skil ræðum við pað menningarlega samhengi sem holdafar ungra kvenlíkama er túlkað út frá. Við fjöllum fyrst um nútímaneyslusamfélag og hugmyndafræði póstfemínisma og pann stað sem hún markar ungum konum.

\section{Kynjað neyslusamfélag}

Á síðustu áratugum hafa tækifæri ungra kvenna til að mennta sig, verða fjárhagslega sjálfstæðar og velja sér starfsvettvang stóraukist. Ýmsir lesa í pessar breytingar sem svo að jafnrétti kynjanna sé náð. Ungar konur purfi einfaldlega að nýta sér frelsi sitt sem einstaklingar til að taka upplýstar ákvarðanir sem hjálpa peim að koma ár sinni fyrir borð í samfélaginu. McRobbie (2009) vísar til pessarar hugmyndafræði sem póstfemínisma og bendir á að hún sé nátengd einstaklingshyggju neyslusamfélagsins. Gill (2017) tekur í sama streng og bendir á að áhrif póstfemínismans megi m.a. greina í pví hvernig markaðsöflin bjóða lausnir til að hámarka árangur kvenna á hinum ýmsu sviðum lífsins. Neyslunni er ætlað að vera bæði valdeflandi og veita ánægju (McRobbie, 2009; Rottenberg, 2018) og er mikið framboð af ráðgjöf og sérfræðipekkingu til að aðstoða konur við að ná markmiðum sínum. Í pví samhengi má benda á að konur eru mikilvægur markhópur 1 afpreyingar- og fjöldamenningu fyrir ráđgjöf um ástarsambönd (Alda Björk Valdimarsdóttir, 2014, 2018), hvernig hægt sé að ná árangri í starfi, prífa heimilið, klæða sig, rækta líkamann og byggja upp sjálfstraust (Riley, Evans, Anderson og Robson, 2019). Oft er petta undir peim formerkjum að konur purfi að læra „,að elska sjálfar sig“ og ná ,að verða besta útgáfan af sjálfum sér" (Gill, 2017). Dessi kynjaða hugmyndafræði leggur jafnframt áherslu á sjálfsögun og sjálfseftirlit sem krefst stöðugrar vinnu, bæði varðandi líkama og sál (Bartky, 1997; Bordo, 1993; Gill, 2007, 2017; McRobbie, 2009).

Nútímaneyslusamfélag einkennist af hröðu upplýsingaflæði og sjónrænum áreitum. Í pví sjónarspili eru ekki allir líkamar jafnir. Gill (2007) bendir á að í hinu sjónræna hagkerfi sé hinn ungi kvenlíkami sérstaklega áberandi. Grannur líkamsvöxtur hefur verið talinn forsenda fegurðar og velgengni, sérstaklega hjá vestrænum konum. Hinn granni og vel pjálfaði líkami er pví bæði fyrirmynd og markmið (Bordo, 1993; Oinas, 1998). Featherstone (2010) bendir á að einstaklingar, sem ekki tekst að standa undir kröfum um að halda sér unglegum og grönnum, eru taldir skorta viljastyrk eða vera með gallaða sjálfsmynd.

Dær rannsóknir sem hér verður sérstaklega gerð grein fyrir skoða pá stöðu sem kvenlíkaminn hefur fengið í orðræðum neyslusamfélagsins. Pær leggja áherslu á hvernig vinnan við hann er annars vegar skilgreind sem fagurfræðilegt verkefni og hins vegar sem hluti af lífsstíl sem hefur раð markmið að tryggja heilsu og vellíðan. Við gerum einnig grein fyrir pví hvernig líkaminn og líkamsgerving (e. embodiment) hafa verið viðfangsefni femíniskra hreyfinga sem gagnrýna fordóma gegn feitum konum, fituskömm og sjúkdómsgervingu feitra líkama.

\section{Kvenlíkaminn sem fagurfræðilegt verkefni}

Degar dregnar eru ályktanir um eiginleika kvenna og siðgæði skipar líkaminn veigamikinn sess (Bordo, 1993). Hann pykir vera fagurfræðilegt verkefni kvenna og í samskiptum kynjanna er hann metinn út frá fegurð og kynpokka (O’Neill, 2017). Thompson (2018) bendir á að útlit hafi orðið enn mikilvægara með tilkomu stefnumótaappa á borð við Tinder. Dar hafi skapast eins konar „,kjötmarkaður“ par sem virði sérstaklega kvenna markast af líkömum peirra og kynpokka. Ungar konur mennta sig í peirri tækni að sýna kynpokkann á viðeigandi hátt sem felur í sér að feta vandratað einstigi milli pess að sýna of mikið/vera of miklar eða að sýna of lítið/hafa ekki nóg (Ásta Jóhannsdóttir, 2018; Riley og Scharff, 2013). Stefnumótin eru mikilvægur vettvangur til að sýna pá tækni. 
Oinas (1998) heldur pví fram að ungar konur sem sífellt eru að fylgjast með og aga líkama sína séu búnar að gera hið ytra (karllæga) augnarád (sem vegur pær og metur) að sínu. Í pví samhengi er áhugavert að rannsóknir frá Svípjóð og Íslandi sýna að ungum konum finnst vinnan við að gera líkamann „frambærilegan“ vera mikil og jafnvel streituvaldandi (Ásta Jóhannsdóttir, 2018; Strömbäck, Formark, Wiklund og Malmgren-Olsson, 2014). McRobbie (2009, bls. 94-98) tekur djúpt í árinni og telur átraskanir og kvíða fylgifiska eða kvilla póstfemínismans og peirrar stífu dagskrár sem ungar konur fylgja með líkama sína til að hámarka möguleika sína í samfélaginu (e. post-feminist disorders). Vinnan við líkamann er stöðug enda einkennist neyslusamfélagið af mikilli hugmyndaauðgi pegar kemur að pví að benda á svæði á kvenlíkamanum sem parfnast athygli (Elias og Gill, 2018). Svo dæmi sé tekið er rýnt í pað hvort konur séu með appelsínuhúð, lærabil (e. thigh gap) og hvort greina megi spik ofan við buxnastrenginn (e. muffin top). Dað kemur pví ekki á óvart að rannsóknir sýni að fjöldi (ungra) kvenna er óánægður með holdafar sitt og sér líkamann sem fyrirstöðu að velgengni í ástarsamböndum (Elias og Gill, 2018). Jafnframt hefur komið fram að pví meira sem pær leggja upp úr rómantískri hugmyndafræði, pví óánægðari eru pær með líkama sína (Sharp og Keyton, 2016). Margt bendir til pess að áhyggjur peirra eigi við rök að styðjast (Smith, Waldorf og Trembath, 1990). Ungir karlmenn í rannsókn Kolbrúnar Hrundar Sigurgeirsdóttur, Dórðar Kristinssonar og Porgerðar Einarsdóttur (2019) og í rannsókn Ástu Jóhannsdóttur (2018) áttu auðvelt með að gagnrýna og benda á annmarka á líkömum kvenna. Í viðtölum O’Neill (2017) sögðust karlmenn frekar hrífast af og vilja fara á stefnumót með konum með grannan líkamsvöxt og í góðu formi. Í rannsókn Ástu Jóhannsdóttur (2018) lýsti ungur karlmaður hneykslun á pví að stúlka sem honum fannst feit skyldi leyfa sér að vera í aðsniðnum fötum. Thompson (2018) bendir einnig á að áreiti gagnvart konum á stefnumótaöppum eins og Tinder beinist oft að holdafari peirra par sem pær eru kallaðar feitar og ljótar. Dannig er stöðugt verið að mæla út líkama ungra kvenna út frá hefðbundnum gagnkynhneigðum viðmiðum par sem konur eru undirskipaðar körlum og í pví hlutverki að sinna pörfum karlanna (sjá einnig Kolbrún Hrund Sigurgeirsdóttir o.fl., 2019).

Rannsóknir benda einnig til pess að útlit og holdafar geti skipt sköpum til að stúlkur fái félagslegt sampykki innan síns jafningjahóps (sjá til dæmis Carey, Donaghue og Broderick, 2010; Gerner og Wilson, 2005). Stúlkur í pessum rannsóknum töldu að vinsælu stúlkurnar væru meðvitaðri um útlit sitt og pyngd, sem bendir til pess að umhirða líkamans sé lykilpáttur í að ná vinsældum og viðhalda peim. Pær bentu jafnframt á að baktal um aðrar stúlkur beindist oft að útliti. Til pess að missa ekki félagslega stöðu sína og forðast stríðni og baktal fannst stúlkunum pær purfa að viðhalda grönnum líkamsvexti (Carey o.fl., 2010). Van Amsterdam (2013) telur að pótt ungmenni af báðum kynjum finni fyrir prýstingi um útlitskröfur og líkamsstærð, virðist prýstingurinn meiri á ungar konur. Ungir karlmenn finni frekar fyrir kröfum um að sýna líkamlegan styrkleika.

\section{Kvenlíkaminn sem heilsufarslegt verkefni}

Í umfjöllun um holdafar og líkama kemur hugmyndin um „lífsstíl“ oft við sögu (van Amsterdam, 2013). Lykilpáttur í heilbrigðum lífsstíl er að huga vel að mataræði. Í pví samhengi má benda á að herferðirsem hafa haft betri heilsu að markmiði leggja mikla áherslu á holdafar og megrun (Campos, 2011; Saguy, Oliver, Gaesser, Campos og Ernsberger, 2005). Sömuleiðis hafa sjónvarpspæettir par sem einstaklingar eru settir á stífa matarkúra og í líkamsrækt nád miklum vinsældum. Áhorfendur fylgja umbreytingarferlinu eftir og fá að sjá og heyra hvernig líf einstaklinganna breytist til hins betra eftir pví sem kílóin hverfa. Deir hætta að vera fangar hins feita líkama og auka meðal annars líkur sínar á að komast í rómantískt samband (Raisborough, 2013). Einstaklingurinn, viljastyrkur hans og vinnan sem hann leggur á sig til að breyta lífsstíl eru í brennidepli og par með er ýtt undir pá hugmynd að feitir einstaklingar séu latir og sýni óábyrga hegðun (Tischner, 2019; Tischner og Malson, 2012). Í samantekt sinni á rannsóknum á pessu sviði bendir Tischner (2019) á að herferðir gegn offitu byggja oft á mjög einföldum boðskap sem leiðir til kvíða og vanlíðunar, sérstaklega hjá stúlkum. Í pví samhengi hefur verið bent á að offita og átröskun eru oft með sömu undirliggjandi áhættupætti og birtast jafnvel samhliða (Peckmezian og Hay, 2017). Svo dæmi sé tekið pá jókst kvíði vegna líkamsútlits og tíðni átröskunarsjúkdóma samfara herferð eða „stríði“ 
gegn offitu í Bandaríkjunum (Greenhalgh, 2012). Рað auðveldar ekki málin að opinber umræða og ráðgjöf um heilbrigt mataræði, lífsstíl og líkamspyngd er oft misvísandi og pverstæðukennd (sjá til dæmis Tischner, 2019).

Í rannsókn van Amsterdam (2013) lýstu ungmenni feitum einstaklingi sem óaðlaðandi manneskju sem bæri ábyrgð á holdafari sínu. Wykes og Gunter (2005) telja að margir tengi grannan líkama við betri heilsu og að hann tengist jafnframt hugmyndum um velgengni og kynpokka. Granni líkaminn verður táknmynd árangurs, góðra breytinga og velgengni og litið fram hjá pví að pyngdartap er ekki alltaf jákvæett.

\section{Líkamsvirðingarhreyfingin}

Síðustu ár hafa ungar konur, meðal annars á Íslandi, tekið sér rými í samfélagslegri umræðu og beitt sér í málefnum sem tengjast kvenlíkamanum (Annadís G. Rúdólfsdóttir og Ásta Jóhannsdóttir, 2018). Samtök um líkamsvirðingu hafa átt sér öfluga málsvara (sjá til dæmis Sigrún Daníelsdóttir, 2016; Margrét Helga Erlingsdóttir, 2019) og hafa pað að markmiði að „,stuðla að virðingu fyrir fjölbreytileika holdafars, jákvæðri líkamsmynd og heilsueflingu óháð holdafari”" (Elva Björk Ágústsdóttir, 2018). Dótt ekki hafi verið gerð kerfisbundin greining á málflutningi samtakanna sýnist okkur pau eiga sér samhljóm með sambærilegum alpjóðlegum hreyfingum. Líkamsvirðingarhreyfingar hafa gagnrýnt fordóma gegn feitum líkömum og lagt sig fram við að trufla ríkjandi orðræður um líkamsfegurð (Tiidenberg og Gómez Cruz, 2015). Dær hafa einnig lagt áherslu á mikilvægi pess að líkamar í öllum stærðum og gerðum séu sýnilegir. Pá hafa pær einnig gagnrýnt fordóma gagnvart feitu fólki í orðræðum samfélagsins, útlitsdýrkun og mismunun á grundvelli holdafars. Kallað hefur verið eftir heildrænni nálgun par sem ekki er einblínt á líkamspyngdarstuðul (BMI) einstaklingsins heldur skoðað hvernig honum líður og hvernig búið er að honum samfélagslega (sjá til dæmis Tischner, 2019; Elias, Gill og Scharff, 2017).

Sastre (2014) gagnrýnir pessar hreyfingar og segir pær stundum festastísömu umbreytingarorðræðu og árangurssögur af megrunarkúrum. Líkt og í sögum af peim umbreytingaráhrifum sem megrun hefur á líf einstaklinga er áhugi á að fólk deili opinberlega sögum sínum af pví hvaða áhrif pað hafði að taka líkamann í sátt. Líkamsvirðingarhreyfingar færa aftur á móti áhersluna frá pví að breyta líkamanum yfir í að breyta hugarfarinu gagnvart líkamanum (Sastre, 2014). Elias o.fl. (2017) benda pó á að orðræður sem hvetja konur til að sættast við og elska líkama sína séu mikilvægt andóf gegn kröfunni um stöđugt sjálfseftirlit auk pess sem pær hvetji konur til pess að hætta að líta á líkama sína sem gallaða. Đær vara aftur á móti við pví að markaðsöfl neyslusamfélagsins nýti pessar hugmyndir til pess að selja vörur. Dær benda á að í markaðssetningu par sem „venjulegir“ líkamar eru hafðir í forgrunni gæti ákveðins tvískinnungs. Fyrirtæki selja vörur sínar með pví að birta myndir af „alvöru“ og „,náttúrulegum“ konum en nota um leið forrit og farða til pess að breyta útliti peirra. Ef konum finnst pær vera feitar, ljótar eða með lítil brjóst er pað peirra vandamál og í peirra valdi að breyta eigin útliti með pví meðal annars að kaupa réttu vörurnar (Elias o.fl., 2017).

Af framangreindum rannsóknum má sjá að birtingarmyndir hins unga kvenlíkama í orðræðum samfélagsins hafa sterk tök á ungum konum. Útlit og holdafar virðist einnig hafa áhrif á virðingarstöðu ungra kvenna í jafningjahópnum, rómantísk tækifæri og vellíðan og pví áhugavert að skoða hvers konar myndir pær sjálfar draga upp af kvenlíkamanum. Rannsóknin sem hér verður gerð grein fyrir var uppistaðan í meistaraverkefni fyrri höfundar og var gögnum safnað með sögulokaaðferð (Clarke, Braun, Frith og Moller, 2019; Clarke, Hayfield, Moller og Tischner, 2017). Leiðarhnoðan er eftirfarandi rannsóknarspurning: Hvaða hugmyndum byggja ungar konur á pegar pær túlka og gera grein fyrir mikilvægi holdafars ungra kvenna í tengslum við stefnumót? 


\section{Aðferð og gögn}

Degar beitt er sögulokaaðferð fá pátttakendur upphaf að sögu (yfirleitt um 1-3 línur) sem peir eru beðnir um að ljúka. Aðferðin er gagnleg við rannsóknir á viðkvæmum málefnum par sem pátttakendur eru ekki beðnir um að ræða um sína eigin persónulegu reynslu heldur skálda sögu (Clarke o.fl., 2017). Dátttakendur hafa mikið svigrúm til að ákvarða hvers konar upplýsingar peir láta frá sér en söguupphafið setur pá alla á sama upphafsreit sem peir skapa síðan sögu út frá. Sögurnar eru skáldskapur en allar eiga pær sér pað sammerkt að til pess að vera skiljanlegar purfa pær að byggja á eða setja fram hugmyndir sem aðrir úr sömu menningu geta borið kennsl á. Rannsóknin snýr enda ekki að pví að meta sannleiksgildi frásagnanna heldur staðsetja pær í menningu pátttakenda og skoða hvaða hugmyndir og gildismat koma par fram (Clarke o.fl., 2019).

Í pessari rannsókn var notað samanburðarsnið sem fól pað í sér að hluti pátttakenda fékk upphaf að sögu par sem sögupersónan Ásdís hafði grennst en aðrir pátttakendur fengu söguupphaf par sem Ásdís hafði bætt á sig. Söguupphafið var prófað áđur en rannsóknin var framkvæmd. Á grundvelli peirrar prófunar var ákveðið að nota orðalagið að Ásdís hefði bætt á sig frekar en að hún hefði fitnað par sem pað pótti minna ,stuðandi“. Degar pátttakendur höfðu lokið sögunni voru peir beðnir um að svara tveimur aukaspurningum. Söguupphafið og spurningar sem tengdust pví voru eftirfarandi:

\section{Saga 1 - sagan um Ásdísi sem hefur grennst}

1. Ásdís er að fara á stefnumót. Hún lítur í spegil og sér að hún hefur grennst. Hvað gerist svo... (skrifið a.m.k. 200 orð/10 línur)

1a. Hvernig myndir pú lýsa Ásdísi?

1b. Lýstu pví hvers vegna og hvernig Ásdís grenntist.

\section{Saga 2 - sagan um Ásdísi sem hefur bætt á sig}

2. Ásdís er að fara á stefnumót. Hún lítur í spegil og sér að hún hefur bætt á sig nokkrum kílóum. Hvað gerist svo... (skrifið a.m.k. 200 orð/10 línur)

2a. Hvernig myndir pú lýsa Ásdísi?

2b. Lýstu pví hvers vegna og hvernig Ásdís bætti á sig.

Rannsóknin fór fram með rafrænum hætti í gegnum SurveyMonkey. Auglýst var eftir pátttakendum í gegnum samfélagsmiðla par sem birt var slóð að rannsókninni. Pegar pátttakendur opnuðu slóðina voru peir fyrst beðnir um að lesa upplýsingar um rannsóknina. Upplýsingasíðan tilgreindi hverjir væru aðstandendur rannsóknarinnar, rannsókninni var lýst, pátttakendum voru kynnt réttindi sín og hvernig tryggt yrði að ekki væri hægt að rekja svörin til peirra. Degar pátttakendur höfðu merkt við að peir hefðu kynnt sér rannsóknina og uppfylltu skilyrði til að taka pátt gátu peir farið inn á aðra síðu par sem hin eiginlega rannsókn hófst og peir voru beðnir um að skrifa sögu. Var pað tilviljun háð hvort söguupphafið pátttakendur fengu. Degar pátttakendur höfðu lokið við að skrifa söguna og svara aukaspurningum voru peir beðnir um að svara fimm bakgrunnsspurningum um hvernig peir skilgreindu kyn sitt, aldur, menntunarstig og hvort peir væru í námi og/eða vinnu (sjá töflu 1). 
Tafla 1. Bakgrunnsupplýsingar um pátttakendur

Heiti

Skilgreining á kyni Kona 71; Transgender 1; Sís kona

Aldur $\quad 18$ ára-2; 19 ára-18; 20 ára-13; 21 árs-9; 22 ára-11; 23 ára-8; 24 ára-11

Hjúskaparstaða Einhleyp 32; í sambandi 28; í sambúð 10; Gift 3; Annað 1 (að hitta strák)

Menntun $\quad$ Grunnskólapróf 21; Framhaldsskólapróf 45; Háskólapróf 7; Iðnmenntun 1

Par sem rannsóknin var rafræn og nafnlaus bauðst pátttakendum að skrá gervinafn við lok pátttöku sem peir gátu notað ef peir vildu draga sig úr rannsókninni síðar.

Upphaflega var markmiðið að fá 40 pátttakendur (20 fyrir hvora sögu) en alls bárust 81 saga, 34 sögur fyrir upphaf 1 og 47 sögur fyrir upphaf 2 . Af peim 81 svörum sem bárust voru 72 sögur greindar, 33 sögur fyrir söguupphaf 1 og 39 sögur fyrir söguupphaf 2 . Ástæðan fyrir pví að ekki allar sögurnar voru greindar var annars vegar sú að sumir pátttakendur svöruðu aðeins bakgrunnsspurningum og luku ekki sögunni og hins vegar að sumar sögurnar voru of stuttar (ein setning) og efnisrýrar. Vert er pó að taka fram að einhverjar styttri sögur voru teknar með í greiningu pví pær sögðu mikið prátt fyrir fá orð. Dæmi um slíka sögu er: „Hún fer í spandex og víðann svartann kjól til að fela“.

Gögnin voru pemagreind samkvæmt aðferð sem kennd er við Braun og Clarke (Terry, Hayfield, Clarke og Braun, 2017). Sögurnar voru fyrst lesnar ítarlega og síðan kóðaðar. Að lokinni kóðun var komið með fyrstu tillögu að pemum og skoðaðar sérstaklega andstæður og sameiginlegir pættir milli sagna sem fengu upphaf 1 eða upphaf 2 . Loks voru settar fram tillögur að lokapemum

\section{Niðurstöður}

Alls voru greind 4 meginpemu: (1) Líkaminn má ekki valda (honum) vonbrigðum, (2) sjálfstraust og líðan tengist ánægju sögupersónu með útlit sitt, (3) líkaminn og sjálfið sem verkefni og loks (4) andóf gegn útlitskröfum er forsenda pess að taka líkamann í sátt. Rauður práður gegnum öll pessi pemu, fyrir utan hið síðasta, er skömmin sem fylgir pví að fitna og vera feitur. Einnig er áhugavert að yfirleitt pegar kyn pess sem Ásdís á stefnumót við er tilgreint virðist gengið út frá pví að pað sé karlmaður og að Ásdís sé gagnkynhneigð. Greiningin er undirbyggð með tilvitnunum úr sögum pátttakenda og eru pær með stafsetningu og orðalagi peirra.

\section{Líkaminn má ekki valda (honum) vonbrigðum}

Раð einkennir petta pema að sögupersónunni er umhugað um að líkami hennar kalli eftir jákvæðum viðbrögðum frá aðilanum sem hún ætlar að hitta á stefnumótinu. Einnig kemur sterkt fram að feitur líkami er talinn líklegur til að valda vonbrigðum, veki jafnvel andstyggð og að virði hans sé minna en virði granns líkama. Granni líkaminn er pess virði að sýna og líklegur til að vekja gleði hjá peim sem hún hittir á stefnumótinu. Samanber: „Hún gleðst yfir árangrinum og pað að hún sé grönn ætti nú að auka líkurnar að stefnumótið verði ekki vonsvikið!““

Í sögum af pví pegar Ásdís hefur fitnað breytist eftirvæntingin í áhyggjur af pví hvort aðrir taki eftir pyngdaraukningunni. Dessar sögur sýna glöggt hvernig söguhetjan er búin að gera hið ytra mælandi augnarád að sínu (Gill, 2007; Oinas, 1998). Hún efast jafnvel um hvort hún eigi að fara pví „hann á eftir að sjá hvað hún er feit.“ Áhyggjurnar beinast aðallega að pví hvort hann muni „dæma hana“ eða „ekki sjá hana eins og hún er“. Hann gæti jafnvel hafnað henni par sem hún hefur villt um fyrir honum og er feit en ekki grönn. Ásdís er pví nánast eins og vara á markaðstorgi sem hægt er að sampykkja eða hafna (sjá til dæmis Thompson, 2018). Petta er einnig í samræmi við niðurstöður úr rannsókn Ástu Jóhannsdóttur (2018) par sem kemur fram 
að ungar konur eru mjög meðvitaðar um hvernig ungir karlar sjá pær.

Hún velti pví fyrir sér hvernig strákurinn myndi bregðast við ef stefnumótið myndi leiða til samræðis og hún klædd í ósmekklegustu flík sína... Sú hugsun varði pó stutt pví hver ætti að vilja sofa hjá pessari hlussu.

Hún hugsar sig um hvort að hún ætti í raun og veru að fara á stefnumótið par sem að petta er kannski ekki líkaminn sem manneskjan sá á myndum af henni á netinu.

Einnig virðist gengið út frá pví að holdafarið gefi vísbendingu um pá manneskju sem sögupersónan hefur að geyma.

Hún vonar að Hlynur, strákurinn sem hún er að fara með á stefnumótið, dæmi hana ekki vegna vaxtarlagsins.

Sumar sögurnar eru martraðarkenndar og snúast um særandi athugasemdir frá öđrum sem setja út á útlit Ásdísar. Dessir aðilar eru í sögunum oftast fyrrverandi kærastar, í einu tilviki ókunnug manneskja á netinu og í annarri samnemandi í skóla. Í einni sögu greinir pátttakandi frá pví að Ásdís hafi grennst til pess að „sýna fyrrverandi hennar hverju hann er að missa af“ pví að hann „gerði svo lítið úr henni fyrir að vera breiðari en aðrar stelpur". Eftir að hafa grennst er hún mjög ánægð með sig en pað breytist pegar hún rekst á fyrrverandi kærasta sinn í bíó á stefnumótinu:

Degar hún mætir í bíóið rekst hún á fyrrverandi og fer allt í einu að fela magann sem sést í prönga bolnum sem hún er í. Hún reynir að fela sig á bakvið Sigga sem stóð í röđinni að kaupa sér popp. Degar fyrrverandi hennar lítur í burtu ætlar hún að hlaupa inná klósettin en pá kallar hann „Ásdís?“ Og hún frýs, „Hvað á ég að gera? Á ég að snúa mér að honum og tala við hann? Eða á ég að hlaupa burt?““ Hugsar hún, en pað var of seint, hann var kominn til hennar. Hún segir „hæ“ og hann segir „Hæ, ég vildi bara spyrja, er leyfilegt fyrir svín að klæðast pröngum fötum?“‘.Við pessi orð hleypur Ásdís heim grátandi og grét restina af nóttinni.

Fyrrverandi kærastinn smánar hana og líkir henni við dýr og er hún í rauninni afmennskuð. Lýsingin á Ásdísi sem „hlussu“ sýnir líka lágt virði og ákveðna andstyggð á líkama hennar og er pað ekki ósvipað pví viðhorfi sem Skeggs (2004) lýsir til líkama lágstéttarkvenna í Bretlandi og Thompson (2018) lýsir í rannsókn sinni á kynferðislegri áreitni á Tinder. Ásdís virðist full af skömm vegna líkama síns og reynir að fela sig frá öđrum. Svipað dæmi birtist í sögu par sem Ásdís er í upphafi mjög ánægð með sig eftir að hafa grennst og ákveður að taka myndir af sér par sem hún er í brjóstahaldaranum og deila peim á samfélagsmiðlum:

Hún deilir nokkrum myndum og fær helling af jákvæðum comment-um. Dessi comment gera hana mjög glaða. Eftir stefnumótið tekur hún fleiri myndir af sér og deilir peim. En á peim myndum kemur 1 ljótt comment. Eftir pað brotnar hún niður og verður mjög ósatt með sjálfa sig og hættir að borða nógu mikið.

Gleði Ásdísar yfir góðum árangri í megruninni endist ekki lengi par sem hið ytra augnaráð setur Ásdísi aftur skorður (samanber Oinas, 1998). Ein ljót athugasemd veldur pví að hún brotnar niður og hættir að borða. Gleðin yfir að ná góðum árangri í megrun markast af pví hversu vel aðrir (sérstaklega mögulegir ástmenn) kunna að meta hann. Sögurnar sýna pá miklu skömm sem söguhetjan finnur fyrir úr umhverfinu fyrir að vera of feit. Vanlíðanin er slík að hún kýs jafnvel að fara ekki úr húsi frekar en valda öðrum vonbrigðum.

Hún hætti að fara út úr húsi nema að pað væri nauðsynlegt pví hún vissi að fólk myndi taka eftir pví að hún væri búin að fitna, í framhaldi af pessari vanlíðan minnkaði hún matarskammtana og á endanum var hún varla að borða neitt yfir daginn. Degar hún grenntist svo pá fór fólk að hrósa henni pví hún væri búin að grennast og henni leið vel í smá stund en hélt samt áfram að borða lítið til að fá meiri athygli og skapaði bara meiri vanlíðan. 
Í pessu pema kemur fram ótti Ásdísar við eftirlit annarra gagnvart líkama sínum. Óttinn beinist aðallega að eftirliti frá einstaklingum sem hún ætlar að hitta á stefnumóti eða fyrrverandi kærustum sem hafa ádur gagnrýnt útlit hennar. Pað eru peir, ungu karlmennirnir, og augnaráð peirra sem skiptir máli. Detta er áhugavert í ljósi niðurstaðna Ástu Jóhannsdóttur (2018) og O’Neill (2017) par sem kom fram að ungir karlmenn vægju virkilega og mætu líkama ungra kvenna. Fram kemur að Ásdís finnur fyrir skömm vegna pess að öðrum finnst hún of feit. Eftirlitið veldur pví að Ásdís setur sér skorður með pví að hætta að borða eða fer jafnvel ekki úr húsi. Skömmin gerir раð аð verkum að henni finnst ástæða til að fela líkama sinn fyrir hinu ytra dæmandi augnarádi. Skömmin er pannig notuð til að hafa taumhald á Ásdísi (sjá einnig Thompson, 2018). Sögurnar sýna einnig að pátttakendur pekkja vel til peirra fordóma sem beinast gegn feitum líkömum (sjá til dæmis Tischner, 2019).

\section{Sjálfstraust og líðan tengist ánægju sögupersónu með útlit sitt}

Í pessu pema kemur fram hversu nátengt sjálfstraust Ásdísar er pví hversu vel henni finnst hún líta út. Til að líta vel út eða virðast heilbrigð parf hún helst að vera grönn. Fatnaður skiptir máli í pessu samhengi og er markvisst notaður af söguhetjunni. Ýmist felur fatnaðurinn líkamsgalla (holdafar) og tekur athyglina frá kroppnum og Ásdísi líður betur eða hann dregur athyglina að henni og líkamanum. Einnig kemur skýrt fram í pessu pema að oft skiptir ekki máli hvort Ásdís sé feit eða grönn, henni finnst hún aldrei líta nógu vel út og sér bara gallana í eigin fari, par af leiðandi er hún kvíðin, óörugg og með lítið sjálfstraust. Líðan Ásdísar er skýrð með viðhorfinu sem hún hefur til sjálfrar sín en einnig peirri menningu sem hefur skapast í vinkonuhópum par sem stúlkur bera sig saman hver við aðra. Veikleikann er bó að finna innra með henni sjálfri pví hún lætur útlitskröfur hafa áhrif á sig.

Eftirfarandi tilvitnun sýnir hvernig sjálfstraustið er tengt pví að söguhetjan er grönn:

Hún finnur annan kjól sem að hún hefur ekki notað lengi. Hún áttaði sig á aldrei á pví hversu fallegur hann væri. Og núna passar hún fullkomlega í hann. Hún lítur ánægð í spegilinn og röltir af stað. Í fyrsta skipti, full sjálfstrausts.

Í pessum sögum kemur fram að liturinn á klæðnaðinum skiptir máli. Rauði liturinn er einungis við hæfi pegar Ásdís lítur vel út, p.e.a.s. er grönn. Detta er áberandi litur sem dregur athyglina að Ásdísi. Svarti liturinn aftur á móti er notaður til að klæða af og leiða athyglina frá líkamanum.

Hún var búin að velja sér að fara í flegnu rauðu skyrtunni en pegar hún var komin í hana leist henni ekki á að láta sjá sig svoleiðis á almanna færi. Hún fór bví aftur í fataskápinn sinn og tætti hin og pessi föt út og var í miklum vandræðum að velja klæðnað sem myndi ekki sýna mikið hold né vera pröngt. Eina sem henni langaði að vera í var svarta skyrtan sem hún hafði verið í síðustu helgi.

Nokkrir pátttakenda lýsa Ásdísi með orðum eins og „pessi týpíska óörugga stelpa“ eða „pessi týpíska stelpa sem er aldrei ánægð með sig." Til dæmis greinir einn pátttakandi frá pví að Ásdís sé „,ýpísk óörugg stelpa sem að kennir pyngdinni um óöryggið“. Vanlíðan Ásdísar er skýrð með skorti á sjálfstrausti og veikri sjálfsmynd: „Hún veit að henni ætti ekki að líða illa við að bæta nokkrum kílóum á sig en ræður ekki við tilfinninguna og brýtur sig niður fyrir pað.“

Veikleiki Ásdísar snýst fyrst og fremst um að hún er of mikið að bera sig saman við aðra. Sögurnar lýsa hversu mikil áhersla er lögð á grannan líkama í jafningjahópnum. Samanburðurinn virðist í pessum tilfellum ekki ólíkur pví sem greina má í vinkonuhópum unglingsstúlkna (sjá til dæmis Carey o.fl., 2010).

Hún reynir að hugsa ekki mikið um útlitið sitt en pað er erfitt pví allar vinkonur hennar segjast vera feitar, pegar pær eru grennri en Ásdís. Hún verður stundum mjög óörugg með sig vegna pess að hún heldur að hún sé feitust í vinahópnum og engin vilji fara með henni á deit eða vera að hitta hana. 
Hún reynir að geðjast jafnöldrum og fylgjast með pví sem er intil pess að fá að vera með en pað er í rauninni óöryggið sem að er að angra hana.

Lýsingum á óöryggi Ásdísar er oft fylgt eftir með útlistun á jákvæðari eiginleikum í fari hennar sem hún sér ekki sjálf, svo sem:

Ásdís er manneskja sem hugsar mikið út í hvað aðrir hugsa en reynir að láta eins og henni sé sama. Hún hugsar mikið um útlit, er kvíðin og svartsýn. Auk pess er hún finasta stelpa, góðhjörtuð og dugleg.

Lýsir einn pátttakandi henni svo: „Hún er óörugg með hvað öðrum finnst [...] ung stelpa sem hefur uppá svo margt fleira að bjóđa en hún telur sjálf." Í grunninn má pví segja að Ásdísi og slæmri sjálfsmynd hennar, sem orsakast m.a. af pví að hún er alltaf að bera sig saman við aðra, sé kennt um pað hversu illa henni lídur.

Í stuttu máli má segja að pátttakendur greina mikið líkamsóöryggi og er áhugavert hvernig sumir pátttakendur lýsa óörygginu sem „týpískum“ eiginleika fyrir stelpu: „Hún er bara hefðbundin stelpa sem er að reyna að vera flott og prúð. Eða sú ímynd sem samfélagið hefur af kvenfólki.“ Detta styður m.a. rannsóknir Strömbäck og félaga (2014) um streituna sem ungum konum finnst fylgja pví að vinna með líkamann. Hugmyndin um að „vera aldrei nóg“ birtist skýrt í pessum sögum. Pessar lýsingar eru einnig í samræmi við greiningar til dæmis Gill (2017) og Rottenberg (2018) á póstfemínisma par sem fram kemur að pað er fyrst og fremst líkaminn og útlit hans sem skilgreinir kvenleikann. Gott útlit verður um leið skilyrði fyrir pví að ungum konum finnist pær valdefldar og með sjálfstraust. Petta kemur einnig skýrt fram í pví hvernig menningunni í vinkonuhópunum er lýst í sögunum. Í sögunum finnst Ásdísi henni stöðugt vera að mistakast að sýna rétt útlit. Dví fylgir óöryggi og kvíði og í kjölfarið fylgir skömm (sjá til dæmis Bartky, 1997).

\section{Líkaminn og sjálfið sem verkefni}

Rauði práđurinn í pessu pema er að konur purfa stöðugt að vinna með líkama sína og sig sjálfar. Vísað er í lífsstíl og jafnvel tímabundin átök til að koma líkamanum í rétt horf. Drástef sem við pekkjum úr nútímasamfélagi, til dæmis að verða besta útgáfan af sjálfum sér (sjá til dæmis Gill, 2017; Rottenberg, 2018), stinga upp kollinum í pessum sögum. Dar er pó lögð áhersla á að Ásdís verði að gæta hófs. Stundum getur vinnan við líkamann farið út fyrir öll skynsemismörk og leitt til átröskunar. Meðalhófið er samt vandratað.

Dátttakendur minnast á lýtaađgerðir sem lausn fyrir Ásdísi. Ein slík saga hefst á pví að Ásdís er ekki viss hvort hún er ánægð með að hafa grennst par sem hún vill „vera smá curvy“ og er að safna sér fyrir lýtaaðgerð til pess að stækka brjóstin og rassinn. Lausnin sem felst í pví að kaupa pjónustu til að laga ,galla“ líkamans er vissulega eitt af pví sem neyslusamfélagið býður upp á (Elias og Gill, 2018; Gill, 2007;).

Í pessu pema kemur sterkt fram að vinnan við líkamann er stöðug og aldrei hægt að slá slöku við.

Hún verður ánægð með sig pví loksins hefur pað tekist. Hún skoðar sig betur í speglinum og hugsar með sér að núna purfi hún bara að missa nokkur kíló í viðbót til pess að hún verði fullkomlega sátt við sig. Ásdís grípur í pröngan kjól sem hún hafði keypt aðeins of lítinn. Hana langar að fara í hann á deitið en hvað ef hún borðaði nú aðeins of mikið? Ef hún yrði panin í lok kvöldsins? Hún gat ekki hugsað sér að hann myndi sjá belginn standa út svo hún greip pirruð í víða skyrtu. Pegar hún væri orðin mjó gæti hún verið flott í öllu pví sem hún vildi, kjóllinn pyrfti bara að bíða.

Í sögunum kemur fram hversu erfitt verkefnið að rækta/temja líkamann er og að pað krefjist pess að setja sér markmið og endurskoða slæmar venjur og lífsstíl. Margir pátttakendur segja frá pví að Ásdís hafi bætt á sig vegna pess að hún hreyfi sig lítið og borði of mikið. Hugtakið „að leyfa sér“ 
er notað en ef Ásdís leyfir sér of mikið fitnar hún. Ef hún er grönn má hún „leyfa sér“ en verður að passa sig. Hér er enn komið inn á hversu erfitt er að finna hinn gullna hófsama meðalveg með líkamann sem m.a. Riley og Scharff (2013) hafa fjallað um. Degar Ásdís er búin að „leyfa sér alltof mikið“ verður hún að „taka sig á“.

Hún svekktir sig pínu yfir pví og hugsar að hún purfi nú að fara taka sig aðeins á í mataræðinu. Hún viðurkennir fyrir sér að hún sé búin að vera leyfa sér alltof mikið af allskonar fæðu og purfi að fara skoða pað aðeins.

Aðrir pátttakendur greina frá pví að Ásdís hafi grennst pví hún neitar sér um mat. Deir nefna til dæmis að hún „hætti að borða“, „,svelti sig fyrir stefnumótið“ eða að hún „,borðaði nær ekkert og æfði 2x á dag“. Í pessu samhengi nefna margir átröskun sem ástæðu fyrir pyngdartapi Ásdísar. Áherslan er á að fólk velur sér lífsstíl og ber sjálft ábyrgð á líkamsástandi sínu.

Hugmyndin um að verða besta útgáfan af sjálfri sér birtist í frásögnum pátttakenda. Sögurnar einkennast af pví að Ásdís ákveður að „taka sig í gegn“ og „vinna í sjálfri sér“ svo henni líði betur með sjálfa sig. Einn pátttakandi lýsir henni sem ,ungri konu með lítið sjálfstraust en hún vill bæta pað og vill verða besta útgáfan af sjálfri sér". Рað koma einnig upp í nokkrum sögum hugmyndir um að Ásdís hefur „valdið“ til pess að grennast ef hún ákveður að pað sé pað sem hún vill. Einn pátttakandinn skrifar: „Ef Ásdísi myndi líða illa með sig á einhvern hátt pá hefur hún valdið til að breyta pví“. Annar pátttakandi segir: „Dessi auka kíló eru fljót að fara ef hún ætlar sér að léttast um nokkur kíló“. Detta er í samræmi við pær miklu áherslur sem lagðar eru í samtímamenningu á að einstaklingurinn beri ábyrgð á sjálfum sér, sinni heilsu og lífsstíl (sjá Tischner, 2019). Mikilvægi pess að vinna með sjálfstraustið og „laga pað“ sést glöggt í annarri sögu par sem Ásdísi er hafnað pví að hún er ósátt með sjálfa sig. Ekki er aðlaðandi að vera með lélegt sjálfstraust:

Í lok kvöldsins labbar deitið Ásdísi heim að dyrum, Ásdís hallar í átt að koss en deitið víkur frá.Ásdís spyr hvað sé að? Deitið svarar „,mér pykir leiðinlegt að sjá svona fallega og sterka konu eins og pig með svona lítið sjálfsálit og pykir mér pað pví miður ekki fallegur eiginleiki. Kannski er best að pú lagir pað áður en petta gengur eitthvað lengra af pví pað er erfitt að elska manneskju sem elskar sig ekki sjálf“.

Einnig koma fram hugmyndir um að Ásdís purfi fyrst að vinna í sjálfri sér ef hún vill verða hamingjusöm og finna sér maka líkt og pessi pátttakandi greinir frá. Hún parf að koma „hausnum“ á sér á sinn besta stað:

Eftir stefnumótið ákveður Ásdís að skoða fjarpjálfanir pví hún vill losna við aukakílóin og verða besta útgáfan af sjálfri sér. Eftir marga daga að hugsa um pessi aukakíló ákveður hún að skrá sig í fjarpjálfun og gengur pað rosalega vel fyrir sig. Hún varð besta útgáfan af sjálfri sér og líður mun betur andlega. Hún ákvað að bjóda manninum aftur á stefnumót par sem hausinn á henni var kominn á sinn besta stað. Stefnumótið gekk eins og í sögu og eru pau búin að vera saman núna í að verða 10 ár og eru 2 börnum ríkari, Ásdísi finnst fjarbjálfunin hafa gjörsamlega breytt henni og hennar hugsunarhætti.

Í pessum lýsingum er lögð áhersla á að Ásdís vinni í sjálfri sér fyrir sjálfa sig. Einn pátttakandi segir svo frá: „Aðeins hún sér breytingarnar í speglinum, enginn annar mun svo sem taka eftir peim. En henni gæti ekki verið meira sama, pessi breyting á lífstíl er bara fyrir hana sjálfa." Pessar hugmyndir eru í samræmi við niðurstöður Shugart (2010) pegar greint var hvaða hvati liggur að baki hjá einstaklingum sem vilja grenna sig. Petta viðhorf einkennir einnig póstfemíniska menningu par sem lausnir við „vandamálum“ kvenna eru settar fram sem skemmtileg verkefni fyrir pær sjálfar (Alda Björk Valdimarsdóttir, 2018; Gill, 2007). 


\section{Andóf gegn útlitskröfum er forsenda pess að taka líkamann í sátt}

Petta pema einkennist af gagnrýninni afstöðu gagnvart peim útlitskröfum sem gerðar eru til ungra kvenna. Gefin er innsýn í innra samtal Ásdísar við sjálfa sig par sem hún ögrar óraunhæfum væntingum um útlit. Petta pema var meira áberandi pegar Ásdís hafði bætt á sig og hugmyndirnar oft í samræmi við málflutning líkamsvirðingarhreyfingarinnar um að við purfum að breyta hugarfari okkar gagnvart líkamanum (Sastre, 2014) og storka ríkjandi hugmyndum um líkamsfegurd (Tiidenberg og Gómez Cruz, 2015).

Andófið gagnvart ríkjandi viðmiðum um líkamsútlit kvenna birtist á pann veg að Ásdís ákveður að vera sátt með sjálfa sig eins og hún er:

Hún fer að hugsa hvort hún eigi nokkuð að fara á stefnumótið. Af hverju er hún búin að bæta á sig? Hún hugsar með sér andskotinn ég sem var orðin svo fin. Svo áttar hún sig á pví að svo lengi sem hún er sátt með sjálfa sig og er með sjálfstraust pá parf hún ekkert annað. Hún má alveg hafa bætt á sig nokkrum kílóum pví hún er ánægð með sig. Hún fer á stefnumótið og pað gengur bara vel. Hún fer ekki í aðhalds buxum!

Hér koma aðhaldsbuxur við sögu og pær fá í sögunum svipaða stöðu og hamlandi lífstykki eldri kynslóða. Ákvörðunin um að fara ekki í aðhaldsbuxur er sett fram sem ákveðin frelsisyfirlýsing. Pó nokkrar sögur par sem Ásdís hefur bætt á sig eru með svipuðum tón. Sögurnar einkennast af pví að Ásdís byrjar að efast um sig en herðir síðan upp hugann og talar fallega til sín: „Hún horfir á sig og segir: „, kona.““"

Sögurnar einkennast margar af ákveðinni afstöðu sem segir ,ég er eins og ég er og mér er sama hvað pér finnst“. Раð er afstaða sem lýsir frelsi frá ípyngjandi útlitskröfum og vellíðan. Kemur pað skýrt fram í pessari frásögn:

Hún fer í kjólinn sem hún æetlar í á stefnumótið, og sér að hann er pínu pröngur á sér, en finnst hún samt líta vel út. Hún setur á sig makeupið og lagar hárið sitt og lítur svo í spegillinn og sér fokking heita stelpu líta aftur á sig. Hún hugsar með sér hverjum er ekki drullu sama að hún hafi bætt pínu á sig henni líour vel í líkamanum sínum og er bara drullu flott.

Einnig kemur fram í nokkrum sögum yfirlýsing Ásdísar um að ef ,deitinu“ líki ekki vel við útlit hennar að pá sé hann ekki pess virði. Má par einnig greina hugmyndina um að valdefling snúist um pað að láta ekki hugmyndir samfélagsins trufla sig.

Ásdís réttir úr bakinu og sléttir úr kjólnum sem hún hafði valið í gær með mestu vissu. Pessi kíló sögðu ekkert um hana og víst væri að stefnumótið hennar tæki aldrei eftir peim. Hún nær í jakkann sinn og slengir hurðinni á eftir sér. Kannski byrfti hún ekki að hafa pessi læti en petta high sem umlykur hana í augnablikinu lætur hana næstum svífa niður stigann. Já! Enginn getur stöðvað hana, og ef einhver ætlar sér að reyna munu pessi svokölluðu aukakíló bara hjálpa til við að ryðja peim úr vegi.

Dessi skemmtilega frásögn lýsir pví hvernig Ásdís fyllist krafti og sjálfstrausti eftir að hafa ákveðið að hætta að efast um sjálfa sig. Pátttakandi lýsir pví að streitan sem Ásdís upplifir sé eðlileg par sem ,við lifum í samfélagi fullkomleika. Par sem allir eru peir einu sem eru ekki fullkomnir.“

Andófið má einnig greina í peim ástæðum sem gefnar eru fyrir pyngdarbreytingum Ásdísar. Nokkrir pátttakendur lýsa ákveðinni frelsun frá sjálfsaga pegar peir voru spurðir hvers vegna og hvernig Ásdís bætti á sig. Ásdís bætir til dæmis á sig ,,vegna pess að hún hefur verið að njóta“ eða að „,hún er hætt að pæla í hverju grammi og líður vel“. Einn pátttakandi segir svo frá: „Hún fór að njóta lífsins frekar en að festast í feðraveldi samfélagsins um útlit og hvernig konur eiga að haga sér." Dessar lýsingar eru mjög femíniskar og benda pær til pess að Ásdís hefur náð að losa 
sig frá samfélagslegum kröfum um sjálfsaga og útlitsviðmið. Andófið er einnig til staðar í sögum par sem Ásdís hefur grennst en ekki með eins afgerandi hætti. Birtist pað á pann hátt að Ásdísi er alveg sama um að hafa grennst. Aðrar sögur segja Ásdísi óánægða með að hafa lést sem pó pykir eftirsóknarvert í nútímasamfélagi og tilgreina að pað sé tilkomið vegna streitu og álags.

Dessar sögur eru gagnrýnar á hvernig ungar konur eru mældar út og pá m.a. af peim sem pær ætla að hitta á stefnumótinu. Ein sagan greinir frá hugsunum Ásdísar: „Ef maðurinn sem hún er að hitta fílar ekki hvernig hún lítur venjulega út pá geta pau ekki verið saman. Hún er eins og hún er.“ Í annarri sögu kippir Ásdís sér lítið upp við að hafa grennst „enda finnst henni að pað ætti ekki að skipta máli hvernig líkaminn hennar lítur út, svo lengi sem henni líður vel í eigin skinni“. Hún minnist einnig pess að fólk hafi gert ráð fyrir pví að hún sé með átröskun vegna pess hversu grönn hún er og vonar að einstaklingurinn sem hún er að fara á stefnumót með ,sé á sama plani og hún sjálf hvað varðar hugmyndir um líkamsvirðingu, og einbeiti sér frekar að pví hve skemmtileg og fyndin hún er, en að skoða líkama hennar". Má hér greina áfram femíniskar hugmyndir í frásögn pátttakanda og á pað sér sterkan samhljóm með greiningum um femíniska orðræðu meðal ungra kvenna á Íslandi (Annadís G. Rúdólfsdóttir og Ásta Jóhannsdóttir, 2018). Einnig eru hér margar tilvísanir í málflutning líkamsvirðingarhreyfingarinnar sem hér eru settar í valdeflandi samhengi (Sastre, 2014; Tiidenberg og Gómez Cruz, 2015).

\section{Lokaorð}

Pó svo að sögurnar séu margar settar fram sem gaman- eða ýkjusögur hafa pær alvarlegan undirtón. Við sjáum samhljóm með sögunum og samfélagsumræðum varðandi ungar konur. Í gegnum sigra og ófarir Ásdísar má greina mikinn prýsting á ungar konur að líta vel út, p.e. vera grannar. Frásagnir pátttakenda endurspegla hversu sjálfsagt pykir að konur setji sjálfum sér skorður og agi líkama sína ef peir eru ekki í samræmi við útlitskröfur samfélagsins (Bordo, 1993). Dar birtist skýrt orðræða hins kynjaða neyslusamfélags sem gerir kröfur um stöðugt sjálfseftirlit og sjálfsaga til að ná árangri (Bartky, 1997; Bordo, 1993; Gill, 2017; Rottenberg, 2018). Einstaklingshyggjan sem einkennir pá samfélagsorðræðu kemur sterkt fram í pví að litið er svo á að pað sé á valdi Ásdísar að laga útlit sitt. Jafnframt kemur hún fram í peim hugmyndum að pað sé undir Ásdísi komið að vinna með „hausinn á sér“ eins og pátttakendur orða pað. Jafnvel pó svo að viðurkennt væri að pað væri sterkur samfélagslegur prýstingur á stúlkur að vera grannar liggur lausnin í að fá pær til að hætta að vera stöðugt að bera sig saman við aðra. Ef sjálfstraustið er ekki í lagi purfa pær að vinna með pær huglægu takmarkanir sem skerða líf peirra. Dær, hugarfar peirra og hégómagirnd eru vandamálið frekar en ípyngjandi útlitskröfur frá samfélaginu.

Sögurnar lýsa einnig vel andstyggðinni sem sumar ungar íslenskar konur upplifa á líkama sínum ef útlit peirra er ekki í takt við samfélagsleg viðmið um kvenleika (sjá einnig Ásta Jóhannsdóttir, 2018). Lýsingar par sem Ásdísi er líkt við svín eða kölluð hlussa afhjúpa hversu miklu máli útlitið skiptir í hugmyndum pátttakenda um ástarsambönd og hvílík skömm fylgir pví að vera feitur. Hlussan er sú sem tekur of mikið rými, svínið er skítugt og ekki mennskt. Kvíðinn og líkamsskömmin fylgir Ásdísi hvort sem hún hefur grennst eða fitnað og hefur á henni sterkt taumhald. Í raun má segja að pær hugmyndir hafi komið fram áður en farið var að safna gögnum en í forprófun á söguupphafi pótti betra að segja að Ásdís hefði „bætt á sig“ en að hún hefði „fitnað“. Dessi krafa um orðalagsbreytingu segir út af fyrir sig mikið um hversu viðkvæmt mál pað er fyrir ungar konur að fitna. Hér skiptir pað máli að söguhetjan er sett í pær aðstæður að hún er að fara á stefnumót en flestir virðast ganga út frá bví að bað sé við karlmann og iðulega gengið út frá pví að hið dæmandi augnaráð tilheyri karlmanni. Hvort sem Ásdís hafði fitnað eða grennst virtist hún bera ótta í brjósti sér um að einstaklingurinn sem hún hafði rómantískan áhuga á myndi dæma hana. Dað er veruleiki sem ungar íslenskar konur pekkja helst til vel (Ásta Jóhannsdóttir, 2018). Valdaskipan samfélagsins kemur skýrt fram par sem pað er hlutverk Ásdísar, ungu konunnar, að bregðast við pörfum unga mannsins sem hún ætlar að hitta á stefnumótinu. Við veltum pví fyrir okkur hvort sögurnar hefðu orðið öðruvísi ef Ásdís hefði til dæmis verið að fara á stefnumót við aðra konu. 
Andófið sem birtist gegn ríkjandi útlitsviðmiðum í mörgum af sögunum er áhugavert en pað birtist sérstaklega í sögum par sem Ásdís hefur bætt á sig. Við veltum pví fyrir okkur hvort slíkar hugmyndir séu áberandi vegna aukinnar umfjöllunar í samfélaginu um líkamsvirðingu og líkamssátt. Valdefling sögupersónunnar pegar hún hefur fitnað felst í pví að hún er að losa sig undan viðjum útlitsviðmiða og er hætt að vera meðvirk með feðraveldinu. Valdeflingin er ekki undir peim formerkjum að sögupersónan hefur náð að vinna 1 sjálfri sér og nád ágæetis árangri í líkamsrækt og megrun heldur er byggt á femíniskri orðræðu sem felur í sér gagnrýni á feðraveldið og pær útlitskröfur sem gerðar eru til kvenna. Degar pessi rannsókn var gerð var \#metoo hreyfingin áberandi í íslensku samfélagi en áður höfðu hreyfingar á borð við \#freethenipple einnig skapað mikla umræðu um líkama ungra kvenna (Annadís G. Rúdólfsdóttir og Ásta Jóhannsdóttir, 2018). Benda pessar niðurstöður til pess að hugmyndir um líkamssátt og mótmæli við útlitskröfum samfélagsins virðist vera að hafa áhrifá orðræður um líkamsútlit. Ungu femínistarnir eru einkum að segja líkamsskömm stríð á hendur en eins og Probyn hefur bent á (2010, sjá tilvitnun í Annadís G. Rúdólfsdóttir og Ásta Jóhannsdóttir, 2018) er líðan kvenna allt önnur pegar líkaminn tengist gleði en pegar hann tengist skömm.

Sögulokaaðferðin veitti áhugaverða innsýn í gildismat og hugmyndir pátttakenda um viðfangsefni rannsóknarinnar. Dó svo að pátttakendur séu ekki beðnir um að lýsa eigin viðhorfum, lífi eða reynslu leita peir í pá pekkingu sem peim er aðgengileg við skrif sögunnar. Við teljum til dæmis ólíklegt að konur fari ekki út úr húsi vegna pess að pær hafi fitnað líkt og greint er frá í pessum sögum. Að pátttakendur hafi látið sér detta í hug sá möguleiki til að bregðast við breytingu á holdafari veitir samt innsýn í ákveðnar orðræður og pær tilfinningar sem tengjast peim. Dannig teljum við gögnin gefa góða innsýn í hugmyndir samfélagsins og pau tök sem pær hafa á ungum konum. Við teljum jafnframt að pað sé á ábyrgð samfélagsins að vinna með einhæfar hugmyndir um kvenleikann sem valda kvíða og vanlíðan frekar en ungra kvenna sem hafa lítið val og litla stjórn á pví hvers konar kvenleika og líkömum er hampað innan samfélagsins.

\section{“This typical, insecure girl": Young women's stories about the importance of women's body weight in a dating scenario}

In Iceland concerns have been raised about the unrealistic body ideals young women are presented with and their impact on self-esteem and body image. Quantitative research confirms these concerns and indeed it seems that women are unhappy with their body weight throughout their life course. At the same time, research into the cultural and social discourses that underpin and shape young women's ideas about the relation between body weight and femininity, has been scant.

This article adopts a feminist poststructuralist framework to explore young women's (18-24 years old) ideas about the importance of body weight when dating. This is based on research that used a story completion methodology to explore the sociocultural ideas participants draw on when making sense of the topic. In the research, participants were randomly presented with either of two different story stems and asked to complete the story. In the first story stem a fictional female character is on her way to a date and notices when she looks in the mirror that she has lost weight. The second story stem is identical apart from the female character noticing that she has gained weight. The participants were approached on social media where they were provided with a link that directed them to the task on SurveyMonkey. In total, 81 participants provided stories. Out of these, 73 stories could be used in this research. When participants had completed their stories they were asked two further questions about the story character and then asked to answer some demographic questions. The stories were analysed thematically. The analysis resulted in 4 themes: (1) the body should not disappoint (him), (2) looks facilitate/are an obstacle to good self-esteem, (3) the body and the self constitute tasks that must be worked on, (4) resistance to body ideals consists in accepting your body. 
It was interesting that most of the participants seemed to assume that the story character was heterosexual and was on her way to meet a man. In the stories collected we saw clear signs of postfeminist discourses where women are presented as the entrepreneurs of their lives, free to make choices that shape their lives. In many of the stories it was assumed that it was the young woman's responsibility to ensure that her body was of value so that she would not disappoint possible lovers and herself. It was also clear that slim bodies were deemed to be of more value than fat bodies. What came across clearly was that it was the young woman's responsibility to work on her body and mind-set so that she could be "the best version of herself". In the stories where the fictional character had gained weight, we detected much body shame and even repulsion towards the fat body. The thought of gaining weight was described as filling the character with much dread and anxiety. When the character had lost weight, she was described as excited about the date but also filled with dread because she anticipated that no matter how much weight she lost it would never be enough. A common description of the story character was that she was a typical anxious and insecure girl who needed to sort herself out; that is, the causes of her problems rested in herself. In contrast, some of the stories seemed to draw on feminist discourses criticising societal pressures on young women to be slim. This resistance was particularly apparent when the character had gained weight. The stories outlined how the story character decided to ignore the slim ideal so that she could accept and love her body. The paper provides an insight into the complex relationship young women have with often hostile socio-cultural ideas about the young female body and the constant surveillance and work those ideas demand from them. We call for a greater interrogation of cultural ideals that either blame young women or their peer group for their anxious relationships to their bodies. We also conclude that the storycompletion method is useful for collecting data. Despite some of the stories seemingly being written in jest they overall presented a rich and nuanced scenario. As such they provide clear insights into the cultural and social discourses participants have access to when writing their stories.

Key words: Gender, body size, femininity, story completion

\section{Um höfundana}

Sólveig Sigurðardóttir (sollasig91@gmail.com) lauk BA-prófi í uppeldis- og menntunarfræði árið 2015 og MA-prófi í uppeldis- og menntunarfræði vorið 2018 frá Háskóla Íslands. Hún starfar sem sérfræðingur hjá Rannsóknamiðstöð Íslands.

Annadís Greta Rúdólfsdóttir (annadis@hi.is) er dósent í aðferðafræði rannsókna við Menntavísindasvið Háskóla Íslands. Hún lauk BA-prófi í sálfræði frá Háskóla Íslands 1989, meistaraprófi í félagssálfræði frá London School of Economics and Political Science árið 1990 og loks doktorsgráđu frá sama skóla í félagssálfræði árið 1997. Rannsóknasvið hennar snúa að mótun kyngervis ungmenna og móðurhlutverkinu.

\section{About the authors}

Sólveig Sigurðardóttir (sollasig91@gmail.com) completed a BA degree in Educational Studies in 2015 and a master's degree in Education Studies from the University of Iceland in 2018. She is now an advisor at the Icelandic Centre for Research.

Annadís Greta Rúdólfsdóttir (annadis@hi.is) is an Associate Professor in Research Methodology in the School of Education at the University of Iceland. She completed a BA in Psychology from the University of Iceland in 1989, a master's degree in 
Social Psychology from London School of Economics in 1990 and completed a PhD in Social Psychology from the same school in 1997. Her research has focused on constructions of gender, youth and motherhood.

\section{Heimildir}

Alda BjörkValdimarsdóttir. (2014). „Ég er ekki punn!“:Tobba Marinós, kvenfrelsisumræðan og skvísumenning. Í Annadís G. Rúdólfsdóttir, Guðni Elísson, Ingólfur Á. Jóhannesson og Irma J. Erlingsdóttir (ritstjórar), Fléttur III: Jafnrétti, menning og samfélag (bls. 11-35). Reykjavík: Háskólaútgáfan.

Alda Björk Valdimarsdóttir. (2018). Jane Austen og ferð lesandans: Skáldkonan í premur kvennagreinum samtímans. Reykjavík: Háskólaútgáfan.

Aníta Estíva Harðardóttir. (2018, 31. ágúst). Erna Kristín segir óraunhæfar kröfur fólks á líkamann vera hræðilega staðreynd. DV. Sótt af https://bleikt.dv.is/bleikt/2018/08/31/erna-kristin-segir-oraunhaefar-krofur-folks-likamann-vera-hraedilega-stadreynd-vill-brjota-stadladar-likamsimyndir-fyrir-fullt-og-allt/

Annadís G. Rúdólfsdóttir. (1997). The construction of femininity in Iceland (doktorsritgerð). London School of Economics and Political Science, University of London. Sótt af http://etheses.lse.ac.uk/2458/

Annadís G. Rúdólfsdóttir og Ásta Jóhannsdóttir. (2018). Fuck patriarchy! An analysis of digital mainstream media discussion of the \#freethenipple activities in Iceland in March 2015. Feminism \& Psychology, 28(1), 133-151. doi:10.1177/0959353517715876

Ásta Jóhannsdóttir. (2018).Young femininity in Iceland and its discontents. Psychology of Women Section Review, 1(1), 17-30.

Bartky, S. L. (1997). Foucault, femininity and the modernization of patriarchal power. Í K. Conboy, N. Medina og S. Stanbury (ritstjórar), Writing on the body: Female embodiment and feminist theory (bls. 129-154). New York: Columbia University Press.

Bordo, S. (1993). Unbearable weight: Feminism, Western culture and the body. Berkeley, Los Angeles: University of California Press.

Campos, P. (2011). Does fat kill? A critique of the epidemiological evidence. Í E. Rich, L. F. Monaghan og L.Aphramor (ritstjórar), Debating obesity: Critical perspectives (bls. 36-59). London: Palgrave Macmillan.

Carey, R. N., Donaghue, N. og Broderick, P. (2010). What you look like is such a big factor: Girls' own reflections about the appearance culture in an all-girls' school. Feminism and Psychology, 21(3), 299-316. doi:10.1177/0959353510369893

Clarke, V., Braun,V., Frith, H. og Moller, N. (2019). Editorial introduction to the special issue: Using story completion methods in qualitative research. Qualitative Research in Psychology, 16(1), 1-20. doi:10.1080/ 14780887.2018.1536378

Clarke,V., Hayfield, N., Moller, N. og Tischner, I. (2017). Once upon a time... Qualitative story completion method. Í V. Braun, V. Clarke og D. Gray (ritstjórar), Collecting qualitative data: A practical guide to textual, media and virtual techniques (bls. 45-70). Cambridge: Cambridge University Press.

Elias, A. S. og Gill, R. (2018). Beauty surveillance: The digital self-monitoring cultures of neoliberalism. European Journal of Cultural Studies, 21(1), 59-77. doi:10.1177/1367549417705604

Elias, A. S., Gill, R. og Scharff, C. (2017). Aesthetic labour: Beauty politics in neoliberalism. Í A. S. Elias, R. Gill og C. Scharff (ritstjórar), Aesthetic labour: Rethinking beauty politics in neoliberalism (bls. 3-49). London: Palgrave Macmillan.

Elva Björk Ágústsdóttir. (2018). Líkamsmynd og fjölbreyttar fyrirmyndir. Samtök um líkamsvirðingu. Sótt af https://likamsvirdingarsamtok.wordpress.com/

Erna Matthíasdóttir, Stefán Hrafn Jónsson og Álfgeir Logi Kristjánsson. (2010). Body weight dissatisfaction in the Icelandic adult population: A normative discontent? European Journal of Public Health, 22(1), 116-121. doi:10.1093/eurpub/ckq178

Featherstone, M. (2010). Body, image and affect in consumer culture. Body E Society, 16(1), 193-221. doi:10.1177/1357034x09354357 
Foucault, M. (1981). The history of sexuality: Volume I. London: Penguin.

Gavey, N. (1989). Feminist poststructuralism and discourse analysis. Psychology of Women Quarterly, 13(4), 459-475.

Gerner, B. og Wilson, P. H. (2005). The relationships between friendship factors and adolescent girls' body image concern, body dissatisfaction, and restrained eating. International Journal of Eating Disorders, 37(4), 313-320.

Gill, R. (2007). Gender and the media. Cambridge: Polity Press.

Gill, R. (2017). The affective, cultural and psychic life of postfeminism: A postfeminist sensibility 10 years on. European Journal of Cultural Studies, 20(6), 606-626. doi:10.1177/1367549417733003

Greenhalgh, S. (2012). Weighty subjects: The biopolitics of the U.S. war on fat. American Ethnologist, 39(3), 471-487. doi:10.1111/j.1548-1425.2012.01375.x

Kolbrún Hrund Sigurgeirsdóttir, Dórður Kristinsson og Dorgerður J. Einarsdóttir (2019). Kynlífsmenninga framhaldsskólanema frá sjónarhorni ungra karla. Netla - Veftímarit um uppeldi og menntun. doi.org/10.24270/ netla.2019.9

Margrét Helga Erlingsdóttir. (2019, 18. janúar). Tara Margrét: „,Dið eruð ekki að hjálpa, pið eruð að gera illt verra“. Vísir. Sótt af https://www.visir.is/g/2019190118749

McRobbie, A. (2009). The aftermath of feminism: Gender, culture and social change. London: Sage.

O'Neill, R. (2017). The aesthetics of sexual discontent: Notes from the London 'seduction community'. Í A. S. Elias, R. Gill og C. Scharff (ritstjórar), Aesthetic labour: Rethinking beauty politics in neoliberalism (bls. 331-351). London: Palgrave Macmillan.

Oinas, E. (1998). The sexy woman and the smart girl: Embodied gender identity and middle-class adolescence. NORA - Nordic Journal of Feminist and Gender Research, 6(2), 78-88. doi:10.1080/08038749850167789

Peckmezian, T. og Hay, P. (2017). A systematic review and narrative synthesis of interventions for uncomplicated obesity: Weight loss, well-being and impact on eating disorders. Journal of Eating Disorders, 5(15), 1-15.doi.org/10.1186/s40337-017-0143-5

Raisborough,J. (2013).Transforming fat bodies: Lifestyle media and corporeal responsibility. Í C.A. Ogden og S. Wakeman (ritstjórar), Corporeality: The body and society (bls. 12-29). Chester: University of Chester Press.

Riley, S., Evans, A., Anderson, E. og Robson, M. (2019). The gendered nature of self-help. Feminism E Psychology, 29(1), 3-18. doi:10.1177/0959353519826162

Riley, S. C. og Scharff, C. (2013). Feminism versus femininity? Exploring feminist dilemmas through cooperative inquiry research. Feminism \& Psychology, 23(2), 207-223. doi:10.1177/0959353512454615

Rottenberg, C. (2018). The rise of neoliberal feminism. Oxford: Oxford University Press.

Saguy, A., Oliver, E., Gaesser, G., Campos, P. og Ernsberger, P. (2005). The epidemiology of overweight and obesity: Public health crisis or moral panic? International Journal of Epidemiology, 35(1), 55-60. doi:10.1093/ ije/dyi254

Sastre, A. (2014). Towards a radical body positive. Feminist Media Studies, 14(6), 929-943. doi:10.1080/1468 0777.2014 .883420

Sharp, E. A. og Keyton, K. (2016). Caught in a bad romance? The negative effect of normative dating and marital ideologies on women's bodies. Sex Roles, 75(1-2), 15-27. doi:10.1007/s11199-016-0610-5

Shugart, H.A. (2010). Consuming citizen: Neoliberating the obese body. Communication, Culture \& Critique, 3(1), 105-126. doi:10.1111/j.1753-9137.2009.01060.x

Sigríður T. Eiðsdóttir, Álfgeir L. Kristjánsson, Inga Dóra Sigfúsdóttir, Garber, C. E. og Allegrante, J. P. (2013). Association between higher BMI and depressive symptoms in Icelandic adolescents: The mediational function of body image. European Journal of Public Health, 24(6), 888-892. doi:10.1093/eurpub/ckt180

Sigrún Daníelsdóttir. (2016, 23. desember). Fögnum okkur. Stundin. Sótt af https://stundin.is/pistill/fognum-okkur/

Smith, J. E., Waldorf,V.A. og Trembath, D. L. (1990). "Single white male looking for thin, very attractive...”. Sex Roles, 23(11-12), 675-685. doi:10.1007/bf00289255

Strömbäck, M., Formark, B., Wiklund, M. og Malmgren-Olsson, E. B. (2014). The corporeality of living stressful femininity:A gender-theoretical analysis of young Swedish women's stress experiences. YOUNG, 22(3), 271-289. doi:10.1177/0973174114533464 
Terry, G., Hayfield, N., Clarke, V. og Braun,V. (2017). Thematic analysis. Í C. Willig og W. Stainton Rogers (ritstjórar), The Sage handbook: Qualitative research in psychology (bls. 17-38). London: Sage.

Thompson, L. (2018). "I can be your Tinder nightmare": Harassment and misogyny in the online sexual marketplace. Feminism and Psychology, 28(1), 69-89. doi:10.1177/0959353517720226.

Tiidenberg, K. og Gómez Cruz, E. (2015). Selfies, image and the re-making of the body. Body and Society, 21(4), 77-102. doi:10.1177/1357034x15592465

Tischner, I. (2019). Tomorrow is the start of the rest of their life — so who cares about health? Exploring constructions of weight-loss motivations and health using story completion. Qualitative Research in Psychology, 16(1), 54-73. doi:10.1080/14780887.2018.1536385

Tischner, I. og Malson, H. (2012). Deconstructing health and the un/healthy fat woman. Journal of Community E Applied Social Psychology, 22(1), 50-62. doi:10.1002/casp.1096

van Amsterdam, N. (2013). Big fat inequalities, thin privilege: An intersectional perspective on 'body size'. European Journal of Women's Studies, 20(2), 155-169. doi:10.1177/1350506812456461

Weedon, C. (1987). Feminist practice and poststructuralist theory. Oxford: Basil Blackwell.

Wykes, M. og Gunter, B. (2005). The media and body image: if looks could kill. Sage: London

Sólveig Sigurðardóttir og Annadís G. Rúdólfsdóttir(2019).

„Dessi týpíska óörugga stelpa“: Greining á sögum ungra kvenna um holdafar og stefnumót

Netla - Veftímarit um uppeldi og menntun. Menntavísindasvið Háskóla Íslands.

Sótt af http://netla.hi.is/greinar/2019/ryn/13

DOI: https://doi.org/10.24270/netla.2019.13 